\title{
Grouping Risks and Threats of Spatial Management of Natural Resource Assets in the National Economy System
}

\author{
Ihor Lytsur $^{1}$, Viktoria Mykytenko² and Oksana Bondar-Pidhurska ${ }^{3, *}$ \\ ${ }^{1}$ Public Institution, Institute of Environmental Economics and Sustainable Development of the National Academy of \\ Sciences of Ukraine, Kyiv, 01032, Ukraine \\ ${ }^{2}$ Public Institution, Institute of Environmental Economics and Sustainable Development of the National Academy of \\ Sciences of Ukraine, Kyiv, 01032, Ukraine \\ ${ }^{3}$ Higher Educational Institution of Ukoopspilka "Poltava University of Economics and Trade", Poltava, 37000, Ukraine \\ *Corresponding author. Email: bondarpodgurskaa@gmail.com
}

\begin{abstract}
The authors formulated and revealed the initial provisions of the functioning and developing spatial natural and economic entities, which were detailed taking into account the basic elements of ensuring a sufficient level of security of the individual, society and state. It is recognized that they should be taken into consideration in the development and implementation in practice the management of the national statebuilding project of modern doctrines and strategies of spatial sustainable development. Methodologically important provisions of the systematized combinatorics of factors of external and internal influence on the organization of spatial natural and economic formations in modern conditions of functioning of the national social and economic system are substantiated. Their difference from the established ones involves the systematization of risks and threats to modern processes of spatial management of natural resources of the state and its regions
\end{abstract}

Keywords: spatial management; risks; threats; natural resources assets; transformation of economic relations

\section{INTRODUCTION}

The relevance of this study is to solve the basic task for society to improve the spatial management system of natural resource assets, increase their usage efficiency and ensure sustainable socio-economic development of Ukraine on this basis. At all levels of the state government, there appeared a need to transform the organizational structure of natural resource management on the basis of the introduction of a modern system of territorial natural entities with the change of relevant functions, mechanisms and powers in the direction of increasing the ecological and economic effect in various spheres of economic activity. The deepening of the conceptual framework for improving the effectiveness of the spatial management system of natural assets also requires the development of an institutional environment, in the context of restructuring the ownership of natural resources, streamlining the powers of the executive authorities, identifying adequate forms of home keeping.

Given the need to find a balance in the structure of natural resources management, the issue of grouping risks and threats to the processes of spatial management of natural resources of the state becomes urgent. In general, efforts should be directed towards ensuring strategic systemintegrated management of the utilization of Ukraine's natural resource potential. This should first and foremost be the formation of an innovative model of state impact on the processes of modernization of the natural and economic sphere, aimed at shifting the center of gravity to superstructure components - managerial innovation; formation of diversified management systems based on the development of neo-industrial economy; ensuring sustainable development of the economy of the country in the conditions of achievement of financial and economic stability, developed rent relations and production of competitive products, formation of the updated in accordance with modern requirements quantitative characteristics of the estimation of the nature management efficiency.

\section{MATERIALS AND METHODS}

The methodological basis of the research is the works of domestic and foreign scientists on the problems of natural resources management, decentralization of powers, sustainable spatial development, as well as normative legal acts of Ukraine, analytical and statistical materials of ministries and departments of Ukraine, international 
organizations, other scientific and informational materials. Research involves the use of a number of interrelated methods, including abstract logic, methods of analysis and synthesis; system analysis; economic and mathematical methods; method of expert assessments; graphic and cartographic methods, etc.

\section{RESULTS AND DISCUSSIONS}

Depending on the degree of respect for the diversity of nature in the theory of sustainable development, there is two schools of scientific thought - "strong" and "weak" sustainability. In the face of strong constancy, natural capital cannot be replaced by human-created capital - that is, artificial capital. Therefore, the first should be no lower than the critical level beyond which it cannot recover. Weak constancy allows substituting the natural resource capital for the artificial one, because, according to the supporters of this approach, scientific and technological progress permits to create factors of production as complete and generalized substitutes for natural capital. At the same time, using the provisions of the theories of weak and strong sustainability, existing approaches to understanding the sustainable development and implementation of the basic principles of the author's concept of spatial management of natural resource assets can be classified as reformist or transformation. Obviously, according to the above, more approaches can be distinguished, but having an aim to identify conceptual differences between the existing ones, only two of the specified approaches were considered in the paper.

The reformist approach encompasses actions to achieve sustainable development within a certain socio-economic system which exists, constantly changes, and therefore requires its moderate reformation. According to the transformational approach, the problems lie in the fundamental properties of modern society and the outdated system of spatial management. Therefore, urgent transformations are needed within the national socioeconomic system, taking into account the increasing different nature of threats and risks to sustainable development. Reformists view economic growth as a way of solving the problems that may arise in the process of achieving sustainable development, because consumer potential is able to increase the global GDP. Transformers, on the other hand, also assume an increase in the consumer needs of the poor, but that should occur due to rationalization of division-redistribution rather than growth. Consumption should be based on criteria of sufficiency. In addition, it should be acknowledged that the provisions of these theoretical and conceptual approaches differ in nature, although both are aimed at ensuring the welfare of mankind and reducing the level of risks: reformist - more anthropocentric, and transformational - eccentric.

It should be noted that anthropocentrism is manifested through humans intervention in natural processes and control over natural resources to meet their own needs. And, in the case of the use of the provisions of ecocentrism, humans control only themselves, namely their activity, not nature. Ecocentrism presupposes the principle of minimal interference in natural systems. A summary of the differences in the above considerations is given in Table 1.

Table 1. Comparative characteristics of reform and transformation approaches in implementing the concept of sustainable development

\begin{tabular}{|c|c|c|}
\hline Characteristic & $\begin{array}{l}\text { Reformist } \\
\text { approach }\end{array}$ & $\begin{array}{c}\text { Transformational } \\
\text { approach }\end{array}$ \\
\hline Essence & $\begin{array}{c}\text { Reforming the } \\
\text { existing socio- } \\
\text { economic system, } \\
\text { changes within the } \\
\text { system }\end{array}$ & $\begin{array}{l}\text { Transforming the } \\
\text { modern socio- } \\
\text { economic system }\end{array}$ \\
\hline $\begin{array}{c}\text { Kind of } \\
\text { sustainability }\end{array}$ & Weak constancy & Strong constancy \\
\hline $\begin{array}{l}\text { The nature of } \\
\text { the approach }\end{array}$ & Anthropocentric & Ecocentric \\
\hline $\begin{array}{l}\text { Attitude to } \\
\text { economic } \\
\text { growth }\end{array}$ & $\begin{array}{c}\text { Economic growth } \\
\text { - consumer } \\
\text { approach }\end{array}$ & $\begin{array}{l}\text { Consumption } \\
\text { redistribution - } \\
\text { sufficiency } \\
\text { approach }\end{array}$ \\
\hline Ideology & $\begin{array}{c}\text { Consumer } \\
\text { ideology }\end{array}$ & $\begin{array}{c}\text { Ideology of } \\
\text { intangible assets }\end{array}$ \\
\hline Driving force & $\begin{array}{c}\text { Business. The role } \\
\text { of the state is } \\
\text { diminished }\end{array}$ & $\begin{array}{l}\text { The State and } \\
\text { public control }\end{array}$ \\
\hline $\begin{array}{c}\text { Means of } \\
\text { implementation }\end{array}$ & $\begin{array}{c}\text { Economic levers } \\
\text { and managerial } \\
\text { techniques }\end{array}$ & $\begin{array}{l}\text { Political actions and } \\
\text { social activities }\end{array}$ \\
\hline $\begin{array}{l}\text { Graphic model } \\
\text { of sustainable } \\
\text { development }\end{array}$ & $\begin{array}{c}\text { Triadic models of } \\
\text { constancy } \\
\text { (triangular, woven } \\
\text { circles) }\end{array}$ & $\begin{array}{c}\text { Nesting model of } \\
\text { constancy } \\
\text { (concentric circles) }\end{array}$ \\
\hline
\end{tabular}

Therefore, the authors propose to carry out activities in the field of improving the level of effectiveness of managing the development of modern spatial natural resources and natural and economic entities, first of all, with simultaneous application of the principles of ensuring ecological and economic security. So, in particular, when considering simple systems (for instance, an enterprise as production and economic system, or forests as ecosystems, etc.), the authors suppose it appropriate to take into account their level of safety (besides the main indicators and, at the same time, the level of economic and environmental safety due to the fact that at present, scientific and technical human activity (labor) causes the transformation of simple systems into more complex entities. And, today, it's hard to talk simply about ecosystems. Nowadays, the vast majority of ecosystems are either man-made or man-controlled (meaning forests, fields, meadows, etc.). Practically, there are no longer sections of areas that are not involved in the production and economic activity by humans - so, now, we are already dealing with created on the territory of the state socio-ecological and economic systems (SEES) [1], which should be distinguished by the types of territorial spatial- 
economic formations (of binary and large-scale invariant orientation).

Based on the definitions of the essence and content of ecological and economic security in its study, there might be two methodological approaches (research: of the ecological and economic security according to the analysis results of the level of load on SEES, and hence, on the development of spatial natural and economic entities; of parameters of sustainability and the balance in functioning the natural-economic formation by the results of evaluation and systems analysis of its indicators). Herewith, ecological and economic security implies the achievement of the maximum productivity of the system, of the minimum disturbance of its equilibrium (quantitative measure of communication between subsystems) under various external influences, increase of resistance to these influences and preservation of ability to self-regeneration. That is, achieving equilibrium interaction between society, production and the natural environment; harmonization of their relations on the basis of observance of laws of development of the biosphere. Ecological and economic security should ensure such internal interaction of elements of the spatial system, at which the high rates of expanded reconstitution of production, economic growth and increase of people's well-being are accompanied by the preservation, continuous improvement and development of both individual spheres and the whole environment.

In reality, solving the task- to ensure a sufficient level of environmental and economic security involves- an organic consideration of the progressive and goal-oriented socioeconomic development of society with its activities to preserve and improve the natural environment. That is, not a rejection of economic growth, but its systematic implementation is not in contradiction, but in complete harmony with the environmental regularities of the development of the surrounding nature, and the social regularities of the development of society. Ecological and economic security is a "reasonable" balance between the maintenance of a favorable ecological environment and the pace of economic development, in the result of which sustainable social progress is ensured. This is possible only under the following conditions: a) an accumulation (restoration) of ecological potential will be occurring, in comparison with the rate of economic potential build-up; b) the speed of anthropogenic action will not exceed the rate of adaptation to external and internal conditions of the general systems. Hence, preservation of these principles will ensure the continuity and practically the limitlessness of economic growth in the current conditions of scientific and technological progress. From this, there will note, a sufficient level of ecological and economic security of spatial natural-economic entities is achieved only when there is warranty, sustainable and long-term development, and at the same time, several key criteria (economic, environmental and social-hygiene) are taken into account. Herewith, as it is known [2], the state of ecological and economic security is determined by analyzing the values of the system of indicators of ecological and economic security (the system of indicators by which we will characterize the state of spatial natural-economic entities: the quantitative information showing the change over time) We recognize that the need for security is one of the most important basic needs of humanity, especially in the field of natural resource management. And, accordingly, in the provisions of Article 3 of the Constitution of Ukraine it is indicated: "A person, his life and health, honor and dignity, integrity and security are determined in Ukraine as the highest social values" [3, p. 4]. Despite the fact that security is not anything objective (material), it is a kind of characteristic and a prerequisite for the vitality and viability of real-world objects. Therefore, it is a very specific category, the main purpose of which is to protect and promote the vital interests of a person, society and the state $[4$, p. 6].

Conditionally, security for both national socio-economic system in general and for spatial natural-economic entities in their limits can be divided into the following two types: a) absolute security: the hypothetical absence of danger, that is, of the possibility of any upheavals, cataclysm, threats to an individual, society or the state as a whole; b) relative safety: real protection against danger, ability to resist it safely in case of occurrence (the possibility of occurrence of danger is not excluded).

Since, by security, we have to understand such state of the subject, which means that the probability of undesirable change of any qualities of the subject, the parameters of his own property and his environment is small (less than a certain threshold limit) [5, p. 44]. That is, the nature destructive (in national and international scales) character of modern scientific and technological progress and economy that has led to serious, sometimes irreversible, disturbances of natural systems and processes must take into account the risk hazard assessment of environmental problems for the development of spatial natural-economic entities. After all, the impact of these problems and the spatial development and going beyond the national framework give them a transboundary and broad international character of threatening actions and significantly reduce the level of national security. Therefore, environmental risks and threats, taking into account their magnitude and importance, make consider environmental security at the level with economic as one of the components of the national security [5, p. 7].

In modern economic theory, there are usually two approaches to the research and study of ecological and economic security, which are developed and taken into account. Some of the developers, in general, reject the need to allocate economic and environmental security into a specific area of research in the context of rationalization of the system of spatial management, but interpret them as ordinary subspecies in the national security system. This position is clearly highlighted by the dominant: "... the principles of not partial hazards, but the only possible systemic security" [6, p. 88]. In this context, economic and environmental destructive factors are considered only in their extremely negative manifestation while the economic and environmental base of society is being destroyed. Hence there appear the attempts to give the activity as to the simultaneous provision of economic and environmental 
security a narrowly instrumental service role, rather than a role of spatial significance - to prevent the transition of security parameters beyond the limit values (development of levels: of anthropogenic load, indicators, etc.). We admit that generalizations of scientific views and results of developments have allowed us to build a closed block diagram of the risk management process within the spatial natural-economic entities (Fig. 1) in five stages of its implementation.

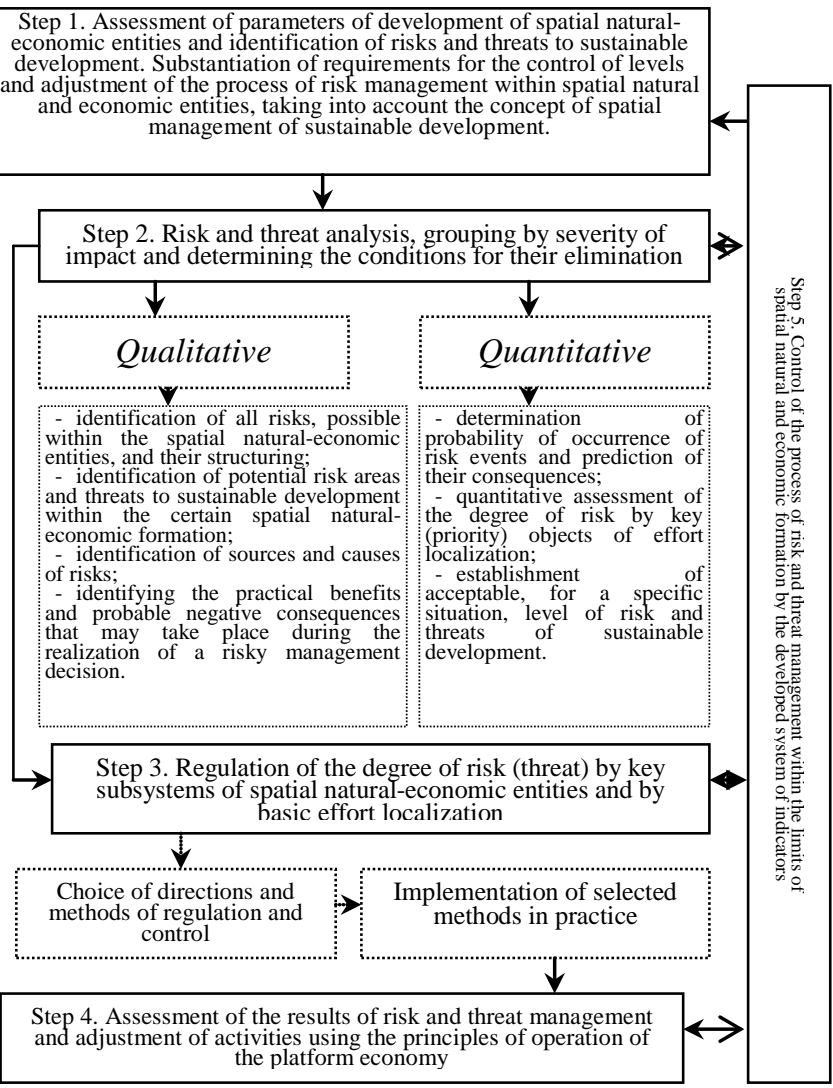

Figure 1. Scheme of the process of risk and threat management within the spatial environment

It should be emphasized that we can identify a set of risks and threats, which are relevant and typical simultaneously for the functioning and development of all-natural and economic entities in Ukraine.

So, in particular, these are: a) the decline in production and the destruction of the real economy, which occurred in the retrospective period; b) structural and technological imbalance of the economy; c) inter-regional disparities in economic development; d) illegal export of capital, raw materials, materials and products outside Ukraine; e) excessively high level of income differentiation and as a result the decline of living standards of the population; g) lack of a socially oriented market economy; h) poor level of health of the population due to the decline in the standard of living; j) inefficient use of natural resource potential; l) the use of worn-out funds and the use of environmentally harmful technologies; m) lack of environmental regulatory framework; $n$ ) low wages and as a result lack of motivation to work; p) technogenic congestion of the territory; d) pollution of the environment and placement of chemically dangerous substances on the territory of Ukraine; c) dominance of the mining and basic industries with a low degree of raw material processing, etc. The presented grouping determines the need to develop, first of all, a basic set of measures for reformatting the general system of management of natural and economic entities in order to eliminate the consequences of implementing the systemic group of risks and prevent the destruction of the parameters of their functioning, shifting equilibrium within their limits and stability. Since, the critical load on the socio-ecological-economic state will accordingly initiate catastrophic (irreversible) changes in the measurements of the functioning of the social, ecological and economic subsystems of natural and economic entities. However, in addition to the above list of established (systemic) risks for Ukraine, including exactly for the development of natural and economic entities, and for making secure their balanced functioning in resource constraints, management entities involved in this problem should pay attention and at risk groups which, in the shortterm perspective, could lead to a crisis or critical situation of the socio-ecological-economic system of natural economic entities (Table 2 shows risks and threats of development of natural and economic entities). 
Table 2. Improved risks structure in the processes of functioning and development of spatial natural and economic entities in Ukraine

\begin{tabular}{|c|c|c|c|c|c|}
\hline \multicolumn{6}{|c|}{$\begin{array}{c}\text { STRUCTURING OF BASIC RISKS AND THREATS } \\
\text { TO PROCESSES OF FORMATION } \\
\text { OF NATURALLY ECONOMIC SYSTEMS }\end{array}$} \\
\hline Technological & External & Organizational & Managerial & Institutional & nal \\
\hline Technical requirements & \multirow{2}{*}{$\begin{array}{l}\text { Climatic conditions, } \\
\text { natural disasters, } \\
\text { urbanization }\end{array}$} & \multirow{2}{*}{$\begin{array}{l}\text { Organizational } \\
\text { complexity }\end{array}$} & $\begin{array}{l}\text { Evaluation and } \\
\text { forecasting system }\end{array}$ & \multirow{2}{*}{$\begin{array}{c}\text { Under-development of systems of } \\
\text { analysis of conformity of internal } \\
\text { development opportunities to } \\
\text { external conditions }\end{array}$} & \multirow{2}{*}{$\begin{array}{l}\text { Commercial and } \\
\text { market risks }\end{array}$} \\
\hline Lack of certification & & & $\begin{array}{c}\text { Control and regulation } \\
\text { procedures }\end{array}$ & & \\
\hline \multirow{2}{*}{$\begin{array}{l}\text { Level of technology, } \\
\text { volumes of introduction } \\
\text { of innovations }\end{array}$} & \multirow{2}{*}{$\begin{array}{c}\text { Peculiarities of } \\
\text { foreign economic } \\
\text { activity }\end{array}$} & \multirow[b]{2}{*}{$\begin{array}{l}\text { Structure of the } \\
\text { resource provision }\end{array}$} & \multirow{2}{*}{$\begin{array}{c}\text { Under-development and } \\
\text { inadequacy of the } \\
\text { communication space }\end{array}$} & $\begin{array}{l}\text { Tax risks } \\
\end{array}$ & \multirow{2}{*}{$\begin{array}{l}\text { Structural and } \\
\text { operational } \\
\text { (production) risks }\end{array}$} \\
\hline & & & & Inflation risks & \\
\hline \multirow{2}{*}{$\begin{array}{c}\text { Inefficiency and } \\
\text { unreliability }\end{array}$} & \multirow{2}{*}{$\begin{array}{c}\text { The scales of natural } \\
\text { resource potential }\end{array}$} & \multirow{2}{*}{\begin{tabular}{|c|}
$\begin{array}{c}\text { Inadequate financing } \\
\text { of development }\end{array}$ \\
\end{tabular}} & \multirow{2}{*}{ Social and team risks } & Crimins & \multirow{2}{*}{ Banking risks } \\
\hline & & & & Politi & \\
\hline \multirow[t]{2}{*}{$\begin{array}{l}\text { Destruction of scientific } \\
\text { and technical potential }\end{array}$} & $\begin{array}{c}\text { Market conditions } \\
\text { and under-developed } \\
\text { markets }\end{array}$ & $\begin{array}{c}\text { The scales of } \\
\text { sustainable } \\
\text { development potential }\end{array}$ & $\begin{array}{c}\text { Under-developed } \\
\text { methodological support }\end{array}$ & Local risks & Insolvency risks \\
\hline & $\begin{array}{c}\begin{array}{c}\text { Medical and social } \\
\text { risks }\end{array} \\
\end{array}$ & \multirow[b]{2}{*}{ Regulatory risks } & \multirow[b]{2}{*}{$\begin{array}{l}\text { Information and } \\
\text { intellectual risks }\end{array}$} & \multirow{2}{*}{$\begin{array}{l}\text { Instability of functioning the } \\
\text { national socio-economic system }\end{array}$} & $\begin{array}{l}\text { Change of } \\
\text { legislation }\end{array}$ \\
\hline Quality & $\begin{array}{l}\text { Demography, } \\
\text { migration }\end{array}$ & & & & $\begin{array}{l}\text { Inadequacy of the } \\
\text { x-institutional } \\
\text { matrix }\end{array}$ \\
\hline
\end{tabular}

However, considering the fact that the formation of spatial natural-economic entities provides their development as business ecosystems, so it requires involvement in the processes of familiarization and use of natural-resource assets, as well as the processes of transformation, transmission and building up the whole set of potentials of natural-economic entities. Hence, the structuring of risks and threats at the present stage of the functioning of the national economy should take into account all the multidirectional factors that arise directly from the use of any elementary components of the strategic potential of natural and economic entities, in general (Table 3)

Table 3. Hierarchical risk structure of spatial development processes in Ukraine by the format of the strategic potential of the state and its regions

\begin{tabular}{|c|c|c|c|}
\hline \multicolumn{2}{|c|}{ HIERARCHICAL STRUCTURE OF RISKS AND THREATS TO SUSTAINABLE DEVELOPMENT } \\
PROCESSES OF NATURAL AND ECONOMIC ENTITIES
\end{tabular}

To summarize, we will note that the hierarchical structure of risks and threats to the sustainable development of Ukraine, given the matrix architecture of strategic potential, will make it possible to identify new groups of risks and threats that are objectified, accordingly, by derivative (owing to the existence of a group of synthetic elementary potentials that form the space of potential for sustainable development of the state) potentials. From this, we will be able to prevent their generation and ensure elimination for a certain period of bias.

Taking into account the experimental and experimental verification of the adequacy [7] of the built models of post- management of natural resource assets [8], social risks [9] in terms of sustainable development of the socio-economic system have a weighting factor of 0.2 , with appropriate importance values the nature of risks and threats to the basic complex of implementation of sustainable management processes in conditions of turbulence in another environment: economic $(0,2)$, production $(0,3)$ and natural resources $(0,3)$. 


\section{CONCLUSION}

According to the generalizations of the scientific schools' development given by the researchers, it is possible to elaborate and propose for each natural economic entities a list of managerial means of influence and bias of the permanent increase of the level of risk by the general risk determinants, which will impede the sustainable development and efficient implementation of economic activity. According to the results of systematization of risks and threats to the processes of spatial management of natural resources assets of the state and its regions, identification of qualitative dimensions and characteristics of the modern socio-ecological and economic system in the disclosure of its five probable states, it is possible to carry out: a) the development of a set of measures for the safe organization (reformatting) of the space of natural and economic formations of Ukraine; b) the construction of the structure of risks and threats, grouping of which provides their delimitation by nature of the four elementary systems of material strategic potential (material, global, factor, of system-universal functioning) with incorporation into their composition of hazards which appear due to the development of derivatives potentially determinant factors that form the scales of the potential for sustainable development.

\section{REFERENCES}

[1] I. M. Lytsur, «Teoretyko-metodolohichni osnovy ekoloho-ekonomichnoi bezpeky (na prykladi lisovykh resursiv Karpat)» [Theoretical and methodological foundations of ecological and economic security (on the example of Carpathian forest resources)]. Nauk. svit, Kyiv, Ukraine, pp.76-77, 2004

[2] O. M. Shapovalova, "Trends of Ecological and Economic Security in the Regions of Ukraine", Efektyvna ekonomika, [Online], vol. 2, 2014, available at: file:///C:/Users/VV/Downloads/efek_2014_2_67.pdf.
[3] The Verkhovna Rada of Ukraine, "Constitution of Ukraine”, Presa Ukrainy, pp. 4-5, 1997

[4] V. O. Kosevtsov, I. F. Bin'ko, «Natsional'na bezpeka Ukrainy: problemy ta shliakhy realizatsii priorytetnykh natsional'nykh interesiv» [National security of Ukraine: problems and ways of realizing priority national interests], NISD, Kyiv, Ukraine, pp. 5-6, 1996

[5] B. M. Danylyshyn, S. I. Dorohuntsov, and V. S. Mischenko, «Pryrodno-resursnyj potentsial staloho rozvytku Ukrainy» [Natural-resource potential for sustainable development of Ukraine], RVPS Ukrainy NAN Ukrainy, Kyiv, Ukraine, pp. 7-44, 1999.

[6] P. Belov, "Systemic basis for ensuring national security of Russia”, Bezopasnost'. vol. 6, pp. 87-88, 1994.

[7] V. Mykytenko, Spatial management of natural resource assets - the key to the development of the national state-building project and its security. Economics of nature management and sustainable development: scientific journal of the State Institution "Institute of Economics of Nature Management and Sustainable Development of the National Academy of Sciences of Ukraine". № 5 (24). pp. 21-28, 2019

[8] V. Mykytenko, I. Lytsur. Threats and risks of implementation of the spatial model of natural resource management. Balanced nature management. № 1. pp. 11-20, 2020

[9] V. Mykytenko, S. Bondarenko, and I. Liganenko, Transformation of public administration in digital conditions: world experience, prospects of Ukraine. Journal of Scientific Papers "Social development \& Security”, Vol. 10, № 2, pp. 76-89, 2020. 